\title{
Activation of estrogen receptors with E2 downregulates peroxisome proliferator-activated receptor $\gamma$ in hepatocellular carcinoma
}

\author{
YUEH-MIN LIN ${ }^{1,2}$, BHARATH KUMAR VELMURUGAN ${ }^{3}$, YU-LAN YEH $^{1,2}$, \\ CHUAN CHOU TU ${ }^{4,5}$, TSUNG-JUNG HO ${ }^{6,7}$, TUNG YUAN LAI ${ }^{8,9}$, CHIH-HAO TSAI $^{3}$, \\ FUU JEN TSAI ${ }^{10}$, CHANG-HAI TSAI $^{11}$ and CHIH-YANG HUANG ${ }^{3,10,12}$
}

\begin{abstract}
${ }^{1}$ Department of Pathology, Changhua Christian Hospital, Changhua; ${ }^{2}$ Department of Medical Technology, Jen-Teh Junior College of Medicine, Nursing and Management, Miaoli; ${ }^{3}$ Graduate Institute of Basic Medical Science, China Medical University, Taichung; ${ }^{4}$ Institute of Medical and Molecular Toxicology, Chung Shan University, Taichung;

${ }^{5}$ Division of Internal Medicine, Armed Force Taichung General Hospital, Taichung; ${ }^{6}$ School of Chinese Medicine, China Medical University, Taichung; ${ }^{7}$ Chinese Medicine Department, China Medical University, Beigang Hospital; ${ }^{8}$ Department of Traditional Medicine, Wan Fang Hospital, Taipei Medical University, Taipei; ${ }^{9}$ Graduate Institute of Pharmacology, College of Pharmacy, Taipei Medical University, Taipei; ${ }^{10}$ Graduate Institute of Chinese Medical Science, China Medical University, Taichung; ${ }^{11}$ Department of Healthcare Administration, Asia University, Taichung;

${ }^{12}$ Department of Health and Nutrition Biotechnology, Asia University, Taichung, Taiwan, R.O.C.
\end{abstract}

Received August 1, 2013; Accepted September 18, 2013

DOI: 10.3892/or.2013.2793

\begin{abstract}
Hepatocellular carcinoma (HCC) is a leading cause of cancer-related mortality and occurs more often in men than in women; however, little is known about its underlying molecular mechanisms. The present study investigated the effect of estrogen receptor (ER) $\alpha$ and ER $\beta$ on peroxisome proliferator-activated receptor $\gamma$ (PPAR $\gamma$ ) expression in Hep3B cells. We examined PPAR $\gamma$, ER $\alpha$ and ER $\beta$ mRNA and protein expression by RT-PCR and western blotting. In order to determine whether PPAR $\gamma$ plays a central role in HCC, we screened for PPAR $\gamma$ expression in liver cancer patient tissues and differentially differentiated HCC cell lines (HA22T, Huh-7, Hep3B and HepG2). We found that PPAR $\gamma$ expression was highly expressed in liver cancer tissues and in Hep3B cells. Furthermore, overexpression of ER $\alpha$ and $E R \beta$ was found to decrease PPAR $\gamma$ expression at the transcriptional as well as at the translational level in a ligand-dependent manner. In summary, the present study demonstrated that both ER $\alpha$ and $\beta$ were sufficient to inhibit PPAR $\gamma$ and provide a valuable therapeutic option for the treatment of HCC patients.
\end{abstract}

Correspondence to: Dr Chih-Yang Huang, Graduate Institute of Basic Medical Science, School of Chinese Medicine, China Medical University, 91 Hsueh-Shih Road, Taichung 404, Taiwan, R.O.C. E-mail: cyhuang@mail.cmu.edu.tw

Key words: peroxisome proliferator-activated receptor $\gamma$, estrogen receptor $\alpha$, estrogen receptor $\beta$, hepatocellular carcinoma, nuclear receptors

\section{Introduction}

Hepatocellular carcinoma (HCC) is the fifth most common cancer worldwide (1) and its frequency is increasing in Southeast Asia, Africa and Western countries. In particular, the mortality rate of HCC in Taiwan has not decreased due to limited treatment options $(2,3)$. HCC occurs more often in men than in women; in addition, males have a poorer prognosis in comparison with females (4). However, little is known about the underlying molecular mechanisms of HCC.

The role of nuclear receptors in HCC development has drawn considerable attention (5). One such example is peroxisome proliferator-activated receptor $\gamma(\operatorname{PPAR} \gamma)$, a ligand-activated transcription factor that is involved in tumor promotion, cellular differentiation and apoptosis $(6,7)$. Several other studies also focused on PPAR $\gamma$ as their target gene to treat various types of cancer, such as colon, thyroid, lung, breast, prostate and liver cancer (8). For example, troglitazone inhibited the growth of human liver cancer cells by inducing apoptosis through caspase-3 activation (9). In breast cancer cells, estrogen receptor (ER) $\alpha$ binds to peroxisome proliferatoractivated receptor response element and negatively interferes with PPAR $\gamma$ signaling (10). Similarly, in preadipocytes cells, ER $\beta$ overexpression inhibits ligand-mediated PPAR $\gamma$ activity, which further results in a blockade of PPAR $\gamma$-induced adipocytic gene expression (11).

Expression ratio of ER $\alpha$ and ER $\beta$ apparently changes during hepatocarcinogenesis (12). A large body of evidence has shown decreased ER $\alpha$ in HCC patients $(13,14)$; similarly, loss of ER $\beta$ expression has been indicated as a common step in the development of colorectal cancer (15). Activation of these ERs controls several biological processes, including cell growth, 
differentiation and apoptosis. However, the effect of ER $\alpha$ or ER $\beta$ on PPAR $\gamma$ expression in HCC is not well studied. In the present study, either ER $\alpha$ or ER $\beta$ is overexpressed by transient transfection and then receptor is activated by $17 \beta$-estradiol. At the same time, we conducted the assay with $17 \beta$-estradiol alone to elucidate whether ligand alone can induce ER $\alpha$ or ER $\beta$ expression in ER-negative Hep3B cells. These results showed that ER $\alpha$ or ER $\beta$ may act as a tumor suppressor in downregulating PPAR $\gamma$ expression in Hep3B cells and were further accelerated by ligand addition.

\section{Materials and methods}

Specimen collection and immunohistochemistry. Written consent was obtained from all patients. Surgical specimens of human liver cancer tissues were obtained by mastectomy from the operating rooms of the Changhua Christian Hospital in Changhua and the China Medical University Hospital in Taichung, Taiwan. Following resection, these specimens were stored at $-70^{\circ} \mathrm{C}$ before being used for the analysis. The tissue biopsy was dried at $58^{\circ} \mathrm{C}$ overnight, dewaxed in xylene for $40 \mathrm{~min}$ and rehydrated in ethanol. Blocking with $3 \% \mathrm{H}_{2} \mathrm{O}_{2}$ in 50\% methanol/50\% phosphate-buffered saline (PBS) and incubated with $5 \%$ cosmic calf serum to reduce non-specific staining of the secondary antibody. Tissue sections were incubated overnight at $4^{\circ} \mathrm{C}$ with PPAR $\gamma(1: 100)$. The sections were washed with PBS and incubated for $1 \mathrm{~h}$ at room temperature with the peroxidase-conjugated secondary antibody. Immunoreactivity was visualized with 3,3'-diaminobenzidine (DAB) substrate (Roche Diagnostics, Mannheim, Germany). After coloring and rinsing with distilled water, the sections were counterstained slightly with Mayer's hematoxylin, dehydrated in graded alcohols, cleared in xylene and detected using microscopy (Olympus, Tokyo, Japan).

Cell culture. The Chang liver cell line, HepG2, Hep3B, Huh-7 and HA22T cells were purchased from ATCC. Chang liver cells were grown in DMEM, HepG2 and Hep3B were grown in MEM (Gibco, Grand Island, NY, USA) and Huh-7 and HA22T cells were grown in DMEM. All media were supplemented with $10 \%$ fetal bovine serum (FBS) (Biochrom AG, Berlin, Germany) and $1 \%$ penicillin streptomycin (Gibco).

Establishment of the double-stable Tet-On/ER $\alpha$ and ER $\beta$ Hep $3 B$ cell line. The double-stable Tet-On/ER $\alpha$ or ER $\beta$ Hep3B cell line, which grows well in the presence of both G418 and hygromycin, was established by plasmid transfection using the Lipofectamine method. Briefly, the primary Tet-On Hep3B cell line was generated by transfecting Hep3B cells with $10 \mu \mathrm{g}$ Tet-On (Clontech Laboratories, Worcester, MA, USA), a regulator plasmid encoding the G418 resistance gene. The primary Tet-On Hep3B cells were then transfected with $10 \mu \mathrm{g}$ of pTRE2/ER $\alpha$ or ER $\beta$ plasmid encoding the hygromycin resistance gene. Double-stable cells were selected with $700 \mu \mathrm{g} / \mathrm{ml}$ G418 and $100 \mu \mathrm{g} / \mathrm{ml}$ hygromycin and further screened for ER $\alpha$ mRNA using DNA sequencing.

Transfection. Hep3B cells were transfected with a plasmid carrying the ER $\alpha$ and ER $\beta$ gene using 10 and $100 \mu \mathrm{M}$ of Lipofectamine (Invitrogen, Auckland, New Zealand) according
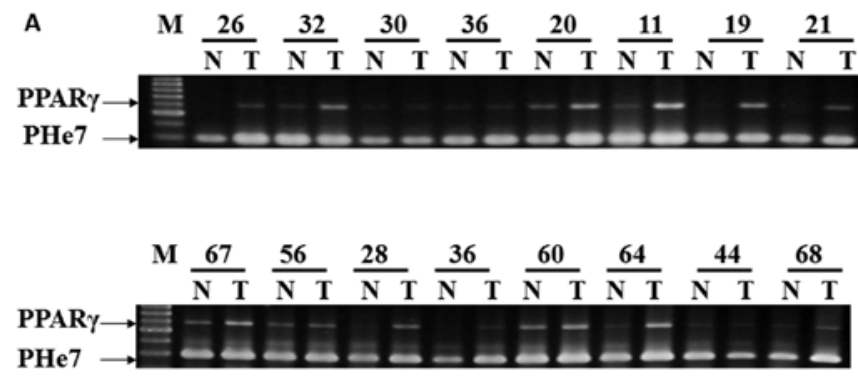

B

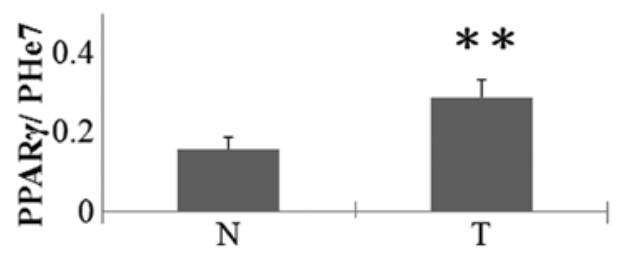

Figure 1. PPAR $\gamma$ expression compared between normal and tumor tissues. The expression of PPAR $\gamma$ in HCC patients was determined by (A) RT-PCR analysis and (B) densitometry analysis of the mRNA expression. M, marker; $\mathrm{N}$, normal tissue; and $\mathrm{T}$, tumor tissue. The data represent the mean $\pm \mathrm{SE}$ of 16 patient specimens $\left({ }^{* *} \mathrm{P} \leq 0.005\right)$.

to the manufacturer's guidelines. After $6 \mathrm{~h}$ of transfection, MEM supplemented with $10 \%$ charcoal/dextran (CD)-FBS (Sigma, St. Louis, MO, USA) was added for $12 \mathrm{~h}$, and MEM containing $1 \%$ FBS and antibiotics were added for $6 \mathrm{~h}$. Prior to treatment, the cells were starved in MEM (no phenol red) with $1 \%$ antibiotics for $6 \mathrm{~h}$ and then replaced with phenol red-free MEM containing $1 \%$ FBS and vehicle or $17 \beta$-estradiol (E2) (Sigma), doxycycline or fenofibrate (Clontech, Mountain View, CA, USA) for different times. These transfection experiments were repeated three times with consistent results.

Reverse transcription (RT). Total RNA was extracted using an Ultraspec $^{\mathrm{TM}}$ kit (Biotecx, Houston, TX, USA) according to the manufacturer's instructions. A total of $4 \mu \mathrm{g}$ of RNA was used for the $\mathrm{RT}$ reaction. $\mathrm{RT}$ was performed at $37^{\circ} \mathrm{C}$ for $60 \mathrm{~min}$ using $55.5 \mu \mathrm{l}$ DEPC $\mathrm{H}_{2} \mathrm{O}, 4 \mu \mathrm{g}$ total RNA, $0.5 \mu \mathrm{l}$ of RNase inhibitor (40 U/ $\mu 1$ ) (Promega, Madison, WI, USA), $20 \mu 1$ of $5 \mathrm{X}$ RT buffer, $8 \mu$ l of dNTP $(2.5 \mathrm{mM}), 10 \mu$ l of oligo(dT) $(5 \mu \mathrm{M} / \mathrm{ml})$ (Mission Biotech, Taipei, Taiwan) and $2 \mu \mathrm{l}$ of MMLV reverse transcriptase (200 U/ $/ \mathrm{l})$ (Promega). The resulting cDNA was added to the PCR mixture containing $9.5 \mu 1$ of DEPC water, $2.5 \mu 1$ of 10X PCR buffer (MD Bio, Taipei, Taiwan), $2.5 \mu 1$ of dNTP $(10 \mathrm{mM})$ (Promega), $2.5 \mu \mathrm{l}$ of each primer $(5 \mu \mathrm{M}), 0.5 \mu \mathrm{l}$ of Taq (2 $\mathrm{U} / \mu \mathrm{l})$ (MD Bio) and $4 \mu \mathrm{l}$ of $2.5 \mathrm{mMdNTP}$ mixture.

Western blotting. Cells were lysed at each time-point with lysis buffer [50 mM Tris base (pH 7.4), $0.5 \mathrm{M} \mathrm{NaCl}, 1 \mathrm{M}$ ethylenediamine-mercaptoethanol (BME), $1 \%$ NP-40\%, 10\% glycerol, Igepal CA-630] (Sigma) and protease inhibitor cocktail tablets (Roche). Proteins were analyzed and separated by $10 \%$ SDS-PAGE, transferred to nitrocellulose membranes and probed with antibodies against the following proteins: PPAR $\gamma$, ER $\alpha$, ER $\beta$ and $\alpha$-tubulin (Santa Cruz Biotechnology, Santa Cruz, CA, USA). The blots were incubated with peroxidaseconjugated secondary antibody for $1 \mathrm{~h}$. Bands were monitored using western blot chemiluminescence reagent (Santa Cruz Biotechnology). 
A

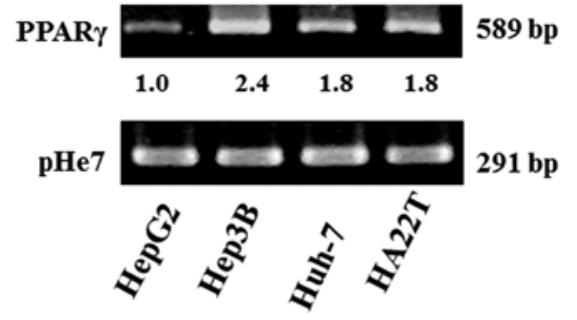

B PPAR $\gamma$

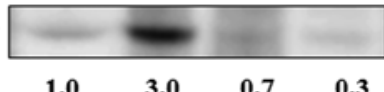

$67 \mathrm{kDa}$

$\alpha$-tubulin

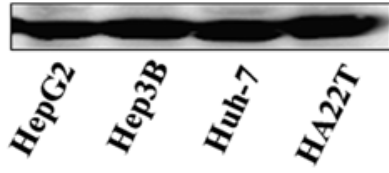

$55 \mathrm{kDa}$

Figure 2. PPAR $\gamma$ expression is screened in Chang liver, HepG2, Hep3B, Huh7 and HA22T cells using (A) RT-PCR and (B) western blotting. For mRNA expression and for protein expression, $\mathrm{pHe} 7$ and $\alpha$-tubulin were used as a loading control individually. All experiments were repeated thrice with similar results.

Statistical analysis. All data are expressed as percentages of the control and mean \pm SD. The results are based on three independent experiments. Student's unpaired t-test was used to compare the differences between groups. Experimental group vs. control group: P-value $<0.05$ was considered to indicate a statistically significant difference; ${ }^{*} \mathrm{P}<0.05$ and ${ }^{* *} \mathrm{P}<0.01$.

\section{Results}

PPAR $\gamma$ expression in HCC is significantly increased in tumor tissues compared with surrounding non-tumorous liver, particularly in poorly differentiated tumor compared to welldifferentiated tumor (16). To assess the role that PPAR $\gamma$ in liver cancer in vivo, we analyzed tumor and non-tumor patient tissues for PPAR $\gamma$ expression. The majority of normal liver tissues do not express PPAR $\gamma$, whereas tumor tissues from the liver cancer patients showed a significant increase in PPAR $\gamma$ expression (Fig. 1).

Next, we analyzed the expression of PPAR $\gamma$ in HCC cells in vitro using HepG2, Hep3B, HuH-7 and HA22T cell lines. As shown in Fig. 2A, RT-PCR analysis readily detected the expression of PPAR $\gamma$ mRNA in all cell lines. Western blot analysis did not display exactly same expression pattern when compared with the mRNA expression. Compared with other cell lines used, only Hep3B cells expressed PPAR $\gamma$ protein (Fig. 2B). These results were consistent with the hypothesis that mRNA levels do not necessarily correlate with the protein expression data (17).

Estrogen exerts its biological function by binding to one of two specific ERs, ER $\alpha$ and ER $\beta$. Thus, the level of exogenous $\mathrm{ER} \alpha$ and endogenous PPAR $\gamma$ in Hep3B cells transfected with empty vector or ER $\alpha$ expression vectors was examined in the presence of E2. As shown in Fig. 3A, ER $\alpha$ containing Hep3B cells induced $\mathrm{ER} \alpha \mathrm{mRNA}$ expression and further decreased PPAR $\gamma$ expression. On the other hand, E2 treatment altered the expression level of ER $\alpha$ and PPAR $\gamma$ in ER $\alpha$ overexpressing Hep3B cells. However, in empty vector transfected Hep3B

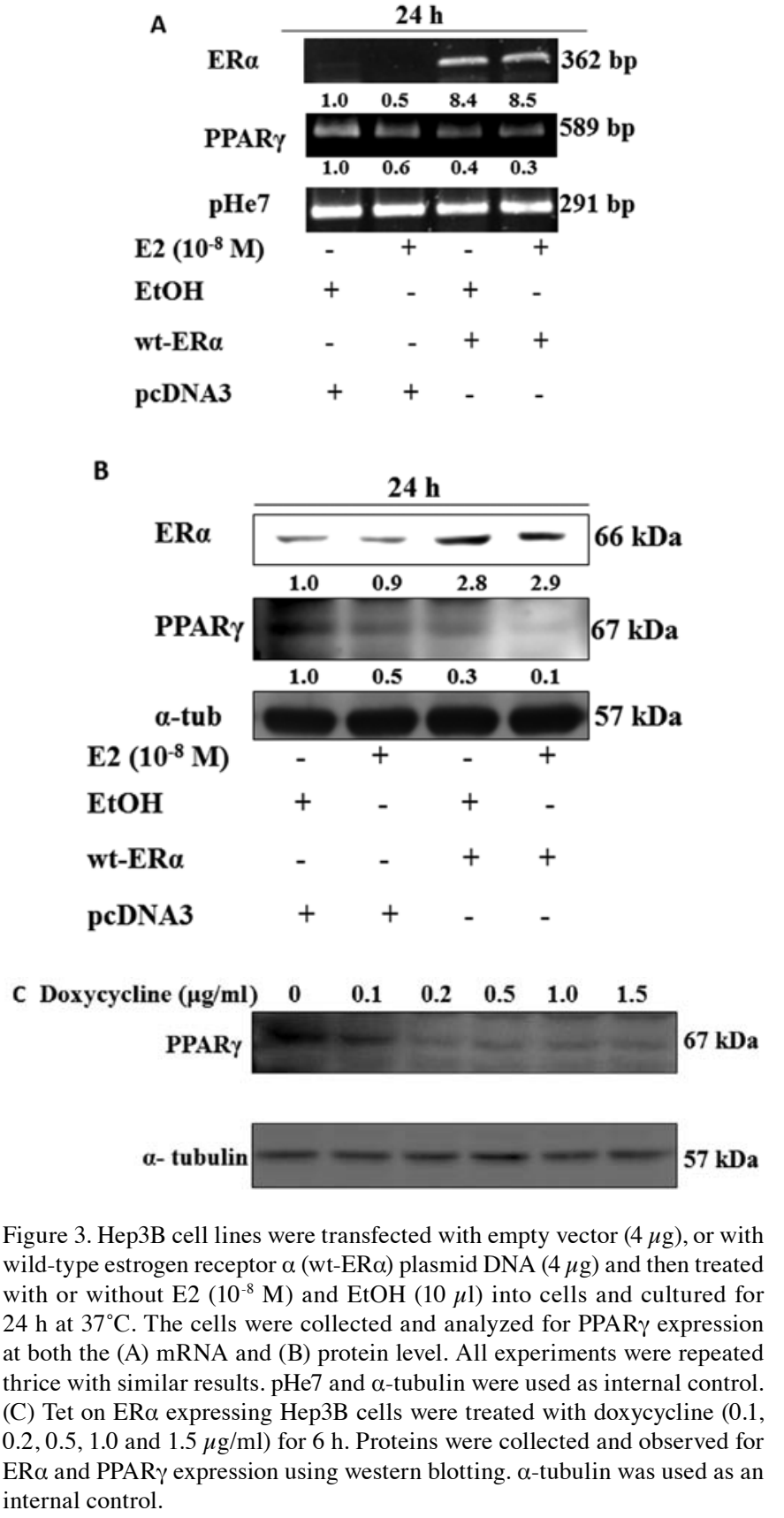

cells, E2 treatment reduced PPAR $\gamma$ mRNA levels without increasing ER $\alpha$ expression. This was further confirmed by western blot analysis (Fig. 3B). We then verified the possibility of ER $\alpha$ in inhibiting PPAR $\gamma$ expression using a stable cell line that expresses ER $\alpha$. Tet-On/ER $\alpha$ Hep3B cells were treated with a range $(0-1.5 \mu \mathrm{g} / \mathrm{ml})$ of Dox for $24 \mathrm{~h}$ and then analyzed for PPAR $\gamma$ expression. As shown in Fig. 3C, a dose-dependent decrease in PPAR $\gamma$ was observed in response to Dox. This was more noticeable at the $0.2 \mu \mathrm{g} / \mathrm{ml}$ concentration.

In order to elucidate whether exogenous expression of $\operatorname{ER} \beta$ inhibits PPAR $\gamma$ expression, vector or ER $\beta$ transfected Hep3B cells were exposed to E2 treatment. No activation of ER $\beta$ and PPAR $\gamma$ was observed in cells transfected with empty vector and in E2 exposed cells. Fig. 4 shows that ER $\beta$ overexpression plus E2 treatment effectively inhibited PPAR $\gamma$ mRNA and protein expression. 
A

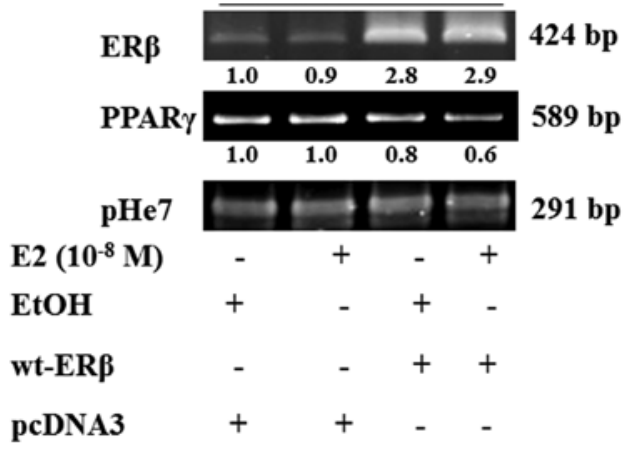

B

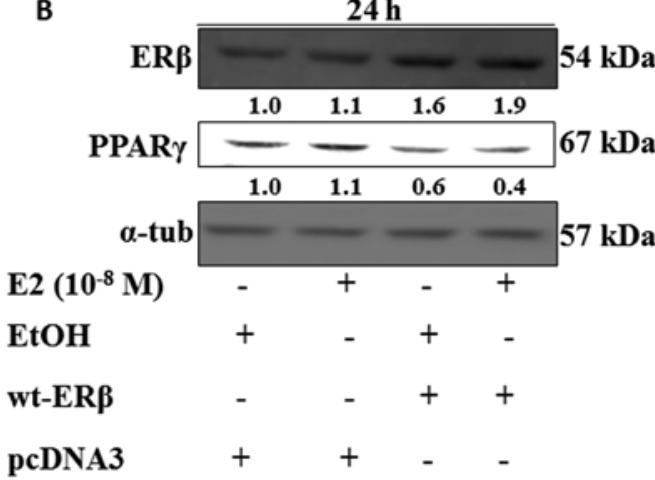

cells constitutively express PPAR $\gamma$ expression at the RNA and protein levels. Having observed significant upregulation of PPAR $\gamma$ expression in Hep3B cells, we next conducted experiments to test the potential role of ERs in inhibiting PPAR $\gamma$ expression in Hep3B cells.

Previous studies showed overexpression of ER $\alpha$ inhibits growth of ECV304 and the Ishikawa cell line by decreasing endothelin-1 and VEGF expression (28). Our results, consistent with a previous report (29), showed that ER $\alpha$ binds with PPAR $\gamma$ and functionally interferes with PPAR $\gamma$ signaling in a ligand-dependent manner. Compared with ER $\alpha$ expression, decreased $\operatorname{ER} \beta$ was found in patients with chronic hepatitis or cirrhosis and in those with HCC. In normal breast cells, ER $\beta$ was found to negatively regulate cellular proliferation. Our data are in agreement with these results, showing ER $\beta$ overexpression decreased PPAR $\gamma$ expression in an E2-dependent manner. Collectively, the present study provided a basic understanding of $E R \alpha$ and $E R \beta$ in PPAR $\gamma$ expression; further studies using these ERs are currently being conducted to elucidate how these ERs control Hep3B cell molecular mechanisms.

\section{Acknowledgements}

This research was funded by the China Medical University (grant no. CMU 101-AWARD-04 and CMU 101-S-18).

\section{References}

wild-type estrogen receptor $\beta$ (wt-ER $\beta$ ) plasmid DNA $(4 \mu \mathrm{g})$ and then treated with or without E2 $\left(10^{-8} \mathrm{M}\right)$ and EtOH $(10 \mu \mathrm{l})$ into cells and cultured for $24 \mathrm{~h}$ at $37^{\circ} \mathrm{C}$. The cells were collected and analyzed for PPAR $\gamma$ expression at both the mRNA (A) and protein (B) level. All experiments were repeated thrice with similar results. pHe7 and $\alpha$-tubulin were used as internal control.

\section{Discussion}

The nuclear receptor superfamily (estrogen, thyroid, glucocorticoid receptors and peroxisome proliferator-activated receptors) plays an important role in controlling cellular homeostasis, and administration of its ligand has been effectively used in cancer treatment (18-21). The role of PPAR $\gamma$ in tumor development is controversial as fewer studies showed ligand activated PPAR $\gamma$ promotes growth inhibition and apoptosis in human esophageal (22) breast (23) ovarian and liver cancer (24) and other reports showed PPAR $\gamma$ ligand could inhibit growth and metastasis of PPAR $\gamma$ positive cancer cells (25). In the present study, we found a significant increase in PPAR $\gamma$ mRNA expression in HCC tissues compared with noncancerous tissues. Similarly, in human lung cancer tissues, increased PPAR $\gamma$ expression was observed compared with non-tumor tissues (25). These findings suggest that PPAR $\gamma$ was involved in hepatocarcinogenesis. However, decreased PPAR $\gamma$ expression in tumor tissue has been observed in human esophageal, breast and ovarian cancer $(22,26,27)$. Therefore, a better understanding of the PPAR $\gamma$ mechanism in different cancer tissues is required.

PPAR $\gamma$ expression has been demonstrated in vitro in several cell lines; particularly in liver cancer cell lines, PPAR $\gamma$ mRNA was expressed at various levels (9). Similarly, we analyzed the effects of PPAR $\gamma$ activation in four human HCC cell lines, compared with the HepG2, Huh-7 and HA22T cells, Hep3B
1. Greten TF, Papendorf F, Bleck JS, et al: Survival rate in patients with hepatocellular carcinoma: a retrospective analysis of 389 patients. Br J Cancer 92: 1862-1868, 2005.

2. El-Serag HB: Hepatocellular carcinoma: recent trends in the United States. Gastroenterology 127: S27-S34, 2004.

3. Weng CJ, Chau CF, Hsieh YS, Yang SF and Yen GC: Lucidenic acid inhibits PMA-induced invasion of human hepatoma cells through inactivating MAPK/ERK signal transduction pathway and reducing binding activities of NF- $\mathrm{KB}$ and AP-1. Carcinogenesis 29: 147-156, 2008.

4. El-Serag HB, Mason AC and Key C: Trends in survival of patients with hepatocellular carcinoma between 1977 and 1996 in the United States. Hepatology 33: 62-65, 2001.

5. Vacca M, Degirolamo C, Massafra V, et al: Nuclear receptors in regenerating liver and hepatocellular carcinoma. Mol Cell Endocrinol 368: 108-119, 2012.

6. Koeffler HP: Peroxisome proliferator-activated receptor $\gamma$ and cancers. Clin Cancer Res 9: 1-9, 2003.

7. Vanden Heuvel JP: Peroxisome proliferator-activated receptors (PPARS) and carcinogenesis. Toxicol Sci 47: 1-8, 1999.

8. Panigrahy D, Singer S, Shen LQ, et al: PPAR $\gamma$ ligands inhibit primary tumor growth and metastasis by inhibiting angiogenesis. J Clin Invest 110: 923-932, 2002.

9. Toyoda M, Takagi H, Horiguchi N, et al: A ligand for peroxisome proliferator activated receptor $\gamma$ inhibits cell growth and induces apoptosis in human liver cancer cells. Gut 50: 563-567, 2002.

10. Wang X and Kilgore MW: Signal cross-talk between estrogen receptor alpha and beta and the peroxisome proliferator-activated receptor gamma1 in MDA-MB-231 and MCF-7 breast cancer cells. Mol Cell Endocrinol 194: 123-133, 2002.

11. Foryst-Ludwig A, Clemenz M, Hohmann S, et al: Metabolic actions of estrogen receptor beta $(\mathrm{ER} \beta)$ are mediated by a negative cross-talk with PPAR $\gamma$. PLoS Genet 4: e1000108, 2008.

12. Wu X, Subramaniam M, Grygo SB, et al: Estrogen receptor-beta sensitizes breast cancer cells to the anti-estrogenic actions of endoxifen. Breast Cancer Res 13: R27, 2011.

13. $\mathrm{Ng} \mathrm{IO}, \mathrm{Ng} \mathrm{M}$ and Fan ST: Better survival in women with resected hepatocellular carcinoma is not related to tumor proliferation or expression of hormone receptors. Am J Gastroenterol 92: 1355-1358, 1997.

14. Jonas S, Bechstein WO, Heinze T, et al: Female sex hormone receptor status in advanced hepatocellular carcinoma and outcome after surgical resection. Surgery 121: 456-461, 1997. 
15. Kennelly R, Kavanagh DO, Hogan AM and Winter DC: Oestrogen and the colon: potential mechanisms for cancer prevention. Lancet Oncol 9: 385-391, 2008.

16. Yu J, Shen B, Chu ES, et al: Inhibitory role of peroxisome proliferator-activated receptor gamma in hepatocarcinogenesis in mice and in vitro. Hepatology 51: 2008-2019, 2010.

17. Borbath I and Horsmans Y: The role of PPAR $\gamma$ in hepatocellular carcinoma. PPAR Res 2008: 209520, 2008.

18. Li MY, Deng H, Zhao JM, Dai D and Tan XY: Peroxisome proliferator-activated receptor gamma ligands inhibit cell growth and induce apoptosis in human liver cancer BEL-7402 cells. World J Gastroenterol 9: 1683-1688, 2003.

19. Lovat PE, Oliverio S, Ranalli M, et al: GADD153 and 12-lipoxygenase mediate fenretinide-induced apoptosis of neuroblastoma. Cancer Res 62: 5158-5167, 2002.

20. Galbiati E, Caruso PL, Amari G, et al: Pharmacological actions of a novel, potent, tissue-selective benzopyran estrogen. J Pharmacol Exp Ther 303: 196-203, 2002.

21. Chen GG, Lee JF, Wang SH, Chan UP, Ip PC and Lau WY: Apoptosis induced by activation of peroxisome-proliferator activated receptor-gamma is associated with Bcl-2 and NF-kappaB in human colon cancer. Life Sci 70: 2631-2646, 2002.

22. Terashita Y, Sasaki H, Haruki N, et al: Decreased peroxisome proliferator-activated receptor gamma gene expression is correlated with poor prognosis in patients with esophageal cancer. Jpn J Clin Oncol 32: 238-243, 2002.

23. Cui Y, Miyoshi K, Claudio E, et al: Loss of the peroxisome proliferation-activated receptor gamma (PPAR $\gamma)$ does not affect mammary development and propensity for tumor formation but leads to reduced fertility. J Biol Chem 277: 17830-17835, 2002.
24. Yu J, Qiao L, Zimmermann L, et al: Troglitazone inhibits tumor growth in hepatocellular carcinoma in vitro and in vivo. Hepatology 43: 134-143, 2006.

25. Li MY, Hsin MK, Yip J, Mok TS, Underwood MJ and Chen GG: PPARgamma activation extinguishes smoking carcinogen by inhibiting NNK-mediated proliferation. Am J Respir Cell Mol Biol 42: 113-122, 2010.

26. Badawi AF and Badr MZ: Expression of cyclooxygenase-2 and peroxisome proliferator-activated receptor- $\gamma$ and levels of prostaglandin $\mathrm{E}_{2}$ and 15 -deoxy- $\Delta^{12,14}$-prostaglandin $\mathrm{J}_{2}$ in human breast cancer and metastasis. Int J Cancer 103: 84-90, 2003.

27. Sakamoto A, Yokoyama Y, Umemoto M, et al: Clinical implication of expression of cyclooxygenase-2 and peroxisome proliferator activated-receptor gamma in epithelial ovarian tumours. Br J Cancer 91: 633-638, 2004.

28. Upla P, Marjomaki V, Kankaanpaa P, et al: Clustering induces a lateral redistribution of $\alpha 2 \beta 1$ integrin from membrane rafts to caveolae and subsequent protein kinase $\mathrm{C}$-dependent internalization. Mol Biol Cell 15: 625-636, 2004.

29. Bonofiglio D, Gabriele S, Aquila S, et al: Estrogen receptor $\alpha$ binds to peroxisome proliferator-activated receptor response element and negatively interferes with peroxisome proliferatoractivated receptor $\gamma$ signaling in breast cancer cells. Clin Cancer Res 11: 6139-6147, 2005. 